\title{
Cardiovascular and nitric oxide response after maximal voluntary isometric contraction in adolescents with and without Down Syndrome
}

\author{
Resposta cardiovascular e de óxido nítrico após contração isométrica voluntária máxima em \\ adolescentes com e sem Síndrome de Down \\ Respuesta cardiovascular y de óxide nítrica después de una contracción isométrica voluntaria \\ máxima en adolescents con y sin síndrome de Down
}

Received: 01/04/2022 | Reviewed: 01/09/2022 |Accept: 01/11/2022| Published: 01/13/2022

Geiziane Leite Rodrigues Melo

ORCID: https://orcid.org/0000-0002-7800-2212

Catholic University of Brasília, Brazil

Email: geizianemelo@hotmail.com

Milton Rocha Moraes

ORCID: https://orcid.org/0000-0003-4818-9650

Catholic University of Brasília, Brazil

Email: mrmoraes70@gmail.com

Weldson Ferreira Abreu

ORCID: https://orcid.org/0000-0001-9025-7165

Catholic University of Brasília, Brazil

Email: ferreiraabreu.weldson@gmail.com

Rafael Reis Olher

ORCID: https://orcid.org/0000-0002-7363-9273

University Center of Center Plateau Apparecido dos Santos, Brazil

Email: rflolher@gmail.com

Lysleine Alves Deus

ORCID: https://orcid.org/0000-0001-5594-3717

Catholic University of Brasília, Brazil

Email: lys.deus@gmail.com

Rodrigo Vanerson Passos Neves

ORCID: https://orcid.org/0000-0002-3257-7870

Catholic University of Brasília, Brazil

Email: rpassosneves@yahoo.com.br

Thiago dos Santos Rosa

ORCID: https://orcid.org/0000-0003-0418-0945 Catholic University of Brasília, Brazil

Email: thiagoacsdkp@yahoo.com.br

Elvio Marcos Boato

ORCID: https://orcid.org/0000-0003-1940-8690 Catholic University of Brasília, Brazil

Email: elvioboato@gmail.com

Samuel R. Hodge

ORCID: https://orcid.org/0000-0002-5297-3731

The Ohio State University, USA

Email: hodge.14@osu.edu

Whitley Stone

ORCID: https://orcid.org/0000-0001-5799-5350

Western Kentucky University, USA

Email: whitley.stone@wku.edu

Dahan Cunha Nascimento

ORCID: https://orcid.org/0000-0002-6580-9404

Catholic University of Brasília, Brazil

Email: dahanc@hotmail.com

\begin{abstract}
This study was designed to compare the cardiovascular and nitric oxide (NO) responses to maximal voluntary isometric contraction (MVIC) with different muscle groups (leg press [LEP] and isometric handgrip [IHG] exercise) of adolescents with Down syndrome (DS) and age-matched non-DS peers. We also compared the absolute and relative IHG strength between groups. Eleven adolescents with DS $(14.1 \pm 1.0$ years $)$ and ten without DS $(13.7 \pm 1.25$ years) participants performed two experimental sessions of LEP and IHG exercises: 1) familiarization session and 2) 3 attempts x 5-sec contraction at MVIC with 3-min rest interval. Blood pressure (BP), heart rate (HR) and NO were collected at rest, immediately post exercise session, and 10-min post-exercise. Measurement saliva NO was performed
\end{abstract}


using the Griess colorimetric method. There were no differences for cardiovascular or NO responses between groups for MVIC. However, DS had a lower but not significantly cardiovascular response at rest and after MVIC tests than those without DS. The DS group displayed a higher $\mathrm{NO}^{-}$concentration at rest, recovery and after IHG when compared to non-DS $(P<0.05)$. In addition, adolescents with DS had a lower level in absolute and relative IHG strength when compared to those without DS $(P=0.001)$. Individuals with DS display a lower cardiovascular response at rest and after MVIC tests and a higher NO response after exercise when compared to the group without DS.

Keywords: Down syndrome; Isometric exercise; Blood pressure; Nitric oxide; Adolescents.

\section{Resumo}

Este estudo teve como objetivo comparar as respostas cardiovasculares e de óxido nítrico (NO) à contração isométrica voluntária máxima (CIVM) com diferentes grupos musculares (leg press [LEP] e preensão manual isométrica [IHG]) de adolescentes com e sem síndrome de Down (SD). Alem de comparar a força IHG absoluta e relativa entre os grupos. Onze adolescentes com SD (14,1 \pm 1,0 anos) e dez sem SD (13,7 \pm 1,25 anos) realizaram duas sessões experimentais de exercícios LEP e IHG: 1) sessão de familiarização e 2) 3 tentativas x 5 segundos de contração na CIVM com 3- intervalo mínimo de descanso. A pressão arterial (PA), a frequência cardíaca (FC) e o NO foram coletados em repouso, imediatamente após a sessão de exercício e 10 minutos após o exercício. A dosagem de NO na saliva foi realizada pelo método colorimétrico de Griess. Não houve diferenças para respostas cardiovasculares e NO entre os grupos para CIVM. No entanto, o SD teve uma resposta cardiovascular menor, mas não significativamente, em repouso e após os testes de CIVM do que aqueles sem SD. O grupo SD apresentou maior concentração de NO em repouso, recuperação e após IHG quando comparado ao grupo não $\mathrm{SD}(\mathrm{P}<0,05)$. Além disso, adolescentes com $\mathrm{SD}$ apresentaram menor nível de força de IHG absoluta e relativa quando comparados àqueles sem $\mathrm{SD}(\mathrm{P}=0,001)$. Indivíduos com SD apresentam menor resposta cardiovascular em repouso e após testes de CIVM e maior resposta de NO após o exercício quando comparados ao grupo sem SD.

Palavras-chave: Síndrome de down; Exercício isométrico; Pressão arterial; Óxido nítrico; Adolescentes.

\section{Resumen}

Este estudio tuvo como objetivo comparar las respuestas cardiovasculares y de óxido nítrico (NO) a la máxima contracción isométrica voluntaria (MVIC) con diferentes grupos de músculos (prensa de piernas [LEP] y agarre isométrico [IHG]) de adolescentes con y sin síndrome de Down (SD) con edad emparejada. Además de comparar la fuerza de IHG absoluta y relativa entre grupos. Once adolescentes con SD (14,1 $\pm 1,0$ años) y diez $\sin$ SD (13,7 $\pm 1,25$ años) realizaron dos sesiones experimentales de ejercicios LEP e IHG: 1) sesión de familiarización y 2) 3 ensayos x 5 segundos de contracción en la MVIC con 3- intervalo mínimo de descanso. La presión arterial (PA), la frecuencia cardíaca (FC) y el NO se recogieron en reposo, inmediatamente después de la sesión de ejercicio y 10 minutos después del ejercicio. La medición de NO en saliva se realizó mediante el método colorimétrico de Griess. No hubo diferencias para las respuestas cardiovasculares y NO entre los grupos para MVIC. Sin embargo, SD tuvo una respuesta cardiovascular menor, pero no significativamente menor, en reposo y después de las pruebas MVIC que aquellos sin SD. El grupo SD tuvo una mayor concentración de NO en reposo, recuperación y después de IHG en comparación con el grupo sin SD $(\mathrm{P}<0,05)$. Además, los adolescentes con SD tenían un nivel más bajo de fuerza de IHG absoluta y relativa en comparación con aquellos sin SD $(\mathrm{P}=0,001)$. Los individuos con SD tienen una respuesta cardiovascular más baja en reposo y después de las pruebas MVIC y una respuesta de NO más alta después del ejercicio en comparación con el grupo sin SD.

Palabras clave: Síndrome de down; Ejercicio isométrico; Presión arterial; Óxido nítrico; Adolescentes.

\section{Introduction}

Down syndrome (DS) is the most prevalent cause of intellectual disability (ID) with approximately 14 per 10,000 children are born with the condition (Presson et al., 2013). The condition is developed due to the triplication of chromosome 21 (Roizen \& Patterson, 2003). Individuals with DS are at greater risk for hypokinetic diseases secondary to a higher prevalence obesity and reduced work capacity compared to the general population (Bertapelli, Pitetti, Agiovlasitis, \& Guerra-Junior, 2016; Fernhall, Mendonca, \& Baynard, 2013). It is well accepted that exercise and physical activity reduce and prevent the risk of various comorbidities (Ginis et al., 2021). In general, people with disabilities have a lower level of physical activity due to sociocultural and economic contexts (Ginis, et al., 2021) and lower physical fitness and muscle strength compared to their peers without DS (Foley \& Killeen, 2019; Pitetti, Climstein, Mays, \& Barrett, 1992).

The physiological profile marked in the DS population has prompted researchers to evaluate neurological and cardiovascular responses to stimuli (Roizen \& Patterson, 2003). Studies have shown an attenuated autonomic response to various sympathomimetic stimuli such as isometric handgrip (IHG), cold pressure test and exercise in this population 
(Kanokwan Bunsawat \& Baynard, 2016; K Bunsawat et al., 2015; Fernhall \& Otterstetter, 2003; Heffernan et al., 2005). This altered autonomic regulation may be due to endothelial dysfunction and attenuated parasympathetic control that will impact vagal withdrawal, peak and rest heart rate (HR) (Baynard, Pitetti, Guerra, \& Fernhall, 2004; Cappelli-Bigazzi et al., 2004; Fernhall, et al., 2013). Changes to heart rate are most often classified under chronotropic incompetence (Leti, Guinot, FavreJuvin, \& Bricout, 2015), but those with DS also endure low work capacity (Fernhall, et al., 2013; Fernhall \& Otterstetter, 2003) and are prone to oxidative stress (Shields et al., 2018).

Adults with DS have lower muscle strength and muscle mass compared to adults without DS (Heffernan et al., 2009; Pitetti, et al., 1992). Researchers lean on IHG as a tool to assess muscle strength in this population, but it is also a great sympathomimetic stimulus and is correlated with all-cause mortality in the general population (Fernhall, et al., 2013; Ortega, Silventoinen, Tynelius, \& Rasmussen, 2012). It was through the use of IHG that investigators identified that though individuals with DS have a functional sympathetic system, there is an attenuated baroreflex sensitivity and altered response to adrenergic stress that can decrease blood pressure (BP) at rest and during exercise (Fernhall, et al., 2013; Heffernan, et al., 2005; Leti, et al., 2015).

IHG exercise may be limited in application as it only produces muscle sympathetic nerve activity across the small activated muscle mass (Fisher, Young, \& Fadel, 2011). Muscle size and strength can influence the pressor response (Fisher et al., 2006; Fisher, et al., 2011), so applicability of IHG to total body physiological response may be questioned. However, Boulton et al., (2019) demonstrated that the cardiovascular responses (BP and HR) were similar in small and large muscles performing isometric exercise.

Bunsawat and Baynard (2016) used IHG and cycle ergometry in adults with DS to evaluate BP and autonomic function. The investigators found normal BP responses and autonomic function with IHG and blunted HR peak and increased diastolic BP on the cycle ergometer. This finding may be related to the observation that children with DS have a high bioavailability of nitric oxide (NO) at rest when compared to the general population (Subramaniam, Girish Babu, \& Mohan Das, 2014). Unfortunately, there are no known studies that have investigated cardiovascular responses to isometric exercise in muscle groups of varying sizes (Baynard, et al., 2004; Kanokwan Bunsawat \& Baynard, 2016; Fernhall \& Otterstetter, 2003).

There is currently one known study that has investigated the bioavailability of salivary NO during acute exercise in young adults with DS (Zambrano, Marquina, Sulbarán, Rodríguez-Malaver, \& Reyes, 2009). Zambrano et al. (2009) found that aerobic exercise had no impact on salivary NO in persons with DS. This study would have been strengthened by including a comparison group and verified the bioavailability of salivary NO after various types of exercise.

Therefore, the purpose of this study was to investigate the influence of MVIC with different muscle groups [Leg Press (LEP) and IHG exercises] on BP, HR, and NO response and to compare IHG and LEP muscle strength in adolescents with and without DS. We hypothesized that both BP and HR responses to MVIC would be higher for non-DS subjects and adolescents with DS would have a higher NO response to MVIC than those without DS. Also, DS group would present a lower muscle strength than non-DS individuals.

\section{Methodology}

\section{Participants}

This cross-sectional study was carried out as part of the Extension and Research Project in Specialized of the Educational Care in Physical Education and Art (dance) for people with disabilities (Levin, 2006). Eleven participants with DS (4 boys, 7 girls) enrolled of this project was selected, which included adolescents with and without DS between 9 and 17 years old and generally healthy. Volunteers had to be diagnosed with DS classified on a medical report as having mild ( $\mathrm{n}=8$ ) to moderate ID ( $\mathrm{n}=3$ ) [ICD-10 code F70 to F71]; participants were able to follow simple verbal instructions. Participants 
without DS (non-DS; $\mathrm{n}=10$, boys $\mathrm{n}=4$ ) were matched on age and gender. Volunteers were excluded if they had any contraindications to exercise based on doctor's advice; cardiologic abnormalities on an electrocardiogram; diabetes mellitus; hypertension; were using medication affecting BP or HR; motor impairments limiting MVIC tests; hypothyroidism and volunteers for the experimental group had to be diagnosed with DS. Parents or legal representatives of adolescents provided written informed consent before participation; volunteers who wanted to participate signed informed assent documents after being told about the study and having been given the chance to ask questions. This study was approved by the Human Research Ethics Committee of Catholic University of Brasilia, Brazil ( ${ }^{\circ}$ 2.419.917/2017) and was performed according to the Declaration of Helsinki.

\section{Study Design}

The study consisted of two sessions. Session one served to collect written informed consent (and assent), assessment of anthropometrics, hemodynamic, neuromuscular and biochemical measures and medical history information were obtained from both groups. Familiarization to all of the study procedures and equipment used for the assessment of MVIC was completed during the first session. Adolescents returned to complete MVIC tests for session two 48-72 hours after session one (Fig. 1).

Figure 1. Experimental design and Time line for BP, HR and NO during the LEP and IHG tests of Maximal Voluntary Isometric Contraction

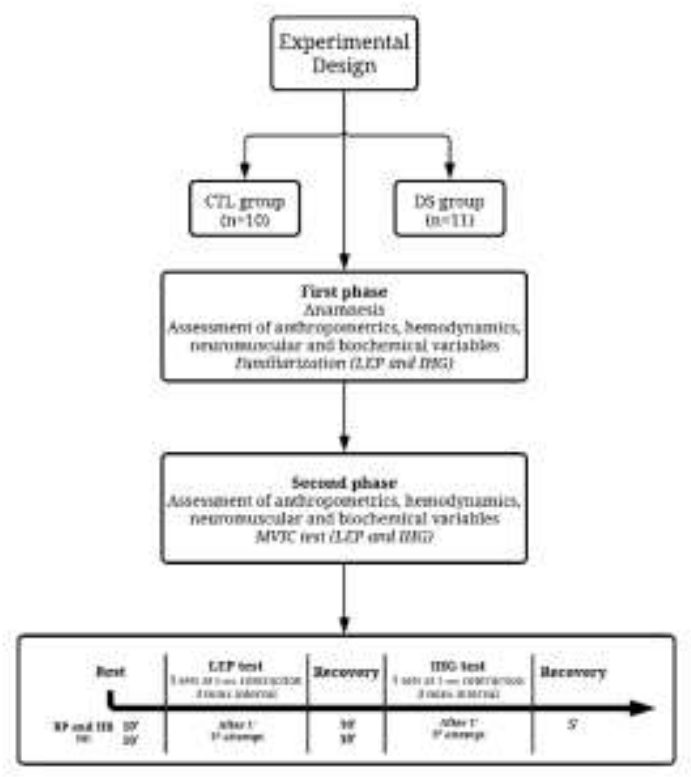

BP, blood pressure; HR, heart rate; NO, nitric oxide; LEP, isometric leg press 45; IHG, isometric handgrip. Fonte: Autores.

Volunteers were instructed to maintain typical nutritional and daily habits of the participants throughout the testing period. Participants were instructed to avoid caffeine consumption, foods high in nitrates (e.g., sausages, beet root), and vigorous physical exercise in the 24 hours prior to each exercise session. 


\section{Anthropometry}

Body mass (Filizola ${ }^{\circledR}$, São Paulo, Brazil) and height (SECA® 214, IL, USA) were measured to calculate body mass index (BMI). Body fat was estimated through the measurement of triceps and subscapular skinfolds following previously published methods (Nascimento et al., 2016). Folds were gathered using a skinfold caliper (Lange ${ }^{\circledR}$, Santa Cruz, CA, USA) and were used for subsequent body fat calculations (Siri, 1993). Fat-free mass (FFM) was then calculated as the difference between total body mass and fat mass.

\section{Hemodynamic Measurement}

BP and HR were measured after 5 and 10-min at rest, 1-min after MVIC attempts, and after 5 and 10-min of recovery

(Fig. 1). All measurements were taken in the sitting position and using the non-dominant arm. Oscillometer equipment (Microlife ${ }^{\circ}$, model BP 3AC1-1, Switzerland) was used to measure BP and a HR monitor (Polar®, model RS800cx, Finland) was used to measure HR. Mean arterial pressure (MAP) and rate pressure product (RPP) were calculated according to Olher $e t$ al. (2020). All measures were taken according to previously published recommendations (Pickering et al., 2005).

\section{Maximal Voluntary Isometric Contraction Tests}

A Power Din Pro ${ }^{\circledR}$ dynamometer (CEFISE ${ }^{\circledR}$, Campinas, Brazil) was used to measure the MVIC in the LEP (Righetto ${ }^{\circledR}$, Campinas, Brazil). The load cell with an accuracy of $200 \mathrm{~kg}_{\text {(CEFISE }}{ }^{\circledR}$, Campinas, Brazil) and sampling frequency of $100 \mathrm{~Hz}$ was coupled in parallel to the load implement axis of the equipment and perpendicular to the plate for LEP (Olher, et al., 2020). A fleximeter (Sanny ${ }^{\circledR}$, São Paulo, Brazil) was used to adjust the knee angle at $90^{\circ}$ for LEP (Escamilla et al., 2001). Volunteers sat on the LEP bench and held the dynamometer Jamar ${ }^{\mathrm{TM}}{ }^{\circledR}$ (Sammons Preston, Illinois, USA) in their dominant hand with their arm positioned parallel to the body, elbow flexed at $90^{\circ}$ and wrist semi-pronated with minimum $\left(<30^{\circ}\right)$ angulation change (Figueiredo IM, 2007). In both protocols, 3 attempts of 5-sec contractions were made, separated by a 3-min interval (Fig.1). A researcher (G.L.R.M) controlled the correct technique and promoted verbal encouragement during each muscle contraction. All testing sessions were scheduled between the of 8:00 AM - 11:00 AM and 2:00 PM - 4:00 PM to maintain convenience for participants and their caregivers. The best MVIC attempts for each assessment was used for further analysis. The best performance from the LEP and IHG were divided by FFM to calculate relative MVIC.

\section{Salivary Nitric Oxide}

Samples of saliva were collected after 10 min of rest, after the third MVIC attempt and 10-min into recovery (Fig. 1). All samples were stored at $-80^{\circ} \mathrm{C}$ for further analysis on an electrochemical biochemical analysis. Saliva was collected with sterile saliva absorbing cotton which was kept in the mouth for 1 minute. This sample was centrifuged at 4000rpm. The bioavailability of $\mathrm{NO}$ was measured by salivary nitrate $\left(\mathrm{NO}_{2}{ }^{-}\right)$, performed using the Griess colorimetric method (Promega Corporation, Madison, USA), and the results were expressed as micromolar $(\mu \mathrm{M})$ (Santana et al., 2013). All samples were evaluated in duplicate and the overall intra- and inter-assays CVs for NO were in a range of 2 to $15 \%$. In addition, the Griess method displays a good agreement with gas chromatography-mass spectrometry and HPPC methods (Romitelli et al., 2007).

\section{Statistical Analyses}

The normality and homogeneity of variances were verified by the Shapiro-Wilk and Levene tests and Mauchly's test of sphericity indicated that the assumption was met. An independent t-test was conducted for descriptive variables. A two-way mixed ANOVA was used to assess the interaction between groups (non-DS vs. DS) and time on systolic BP (SBP), diastolic BP (DBP), MAP, RPP, HR and NO. Considering the non-normal distribution of NO, the concentrations were log-transformed to derive a near-normal distribution. In case of no time $\mathrm{x}$ group interaction, main effects for the two within-subjects factors were conducted. For the effect size, the following conventions were adopted for two-way mixed ANOVA: $f=0.10$ (small), $f=$ 0.25 (medium) and $f=0.40$ (large) (Cohen, 2013). Also, Cohen's d was used to quantify the effect size of NO comparisons between groups. Cohen's d effect sizes were computed and interpreted as small $=0.3$; medium $=0.5$; large $=0.8($ Cohen, 
2013). In order to minimize type II error in comparisons for NO, a Mann-Whitney test was used to verify possible differences among delta $(\Delta)$, which were calculated as follows: $\Delta=$ recovery minus baseline and after handgrip minus baseline.

The test and retest reliability of IHG and LEP MVIC tests were determined by the intraclass correlation coefficients (ICC). Results from ICC tests were interpreted as follows: 0-0.2 poor; 0.3-0.4 fair; 0.5-0.6 moderate; 0.7-0.8 strong and > 0.8 almost perfect (Portney \& Watkins, 2009). The smallest real difference (SRD) was calculated for LEP and IHG based on the test-retest correlation with the pooled (test + retest) standard deviation (SD) using an equation previously reported and the standard error of measurement $(\mathrm{SEM})=\mathrm{SD} \sqrt{ }(1-\mathrm{ICC}$ or Person's r) was also multiplied by $1.96 \sqrt{2}$ to obtain the SRD (Dvir, 2015). To calculate the technical error (TE), the standard deviation from test-retest differences was divided by $\sqrt{2}$ (Swinton, Hemingway, Saunders, Gualano, \& Dolan, 2018). A post-hoc power analysis was conducted for NO delta percent change during recovery, and considering an effect size of 1.98 , and an alpha error of 0.05 , the power for this study was 0.95 . A level of $P \leq 0.05$ was considered significant. All procedures were performed by the Statistical Package for Social Sciences ver. 18.0 (SPSS Inc., Chicago, IL, USA), GraphPad Prism 6.0 (San Francisco, CA, USA), and G*Power 3.1.6.(Faul, Erdfelder, Lang, \& Buchner, 2007) All data are freely available for examination at DOI: dx.doi.org/10.17504/protocols.io.bztgp6jw.

\section{Results}

Descriptive data are presented in Table 1. Adolescents with DS were shorter than non-DS participants. There were no other differences identified for anthropometric variables. Absolute and relative IHG were different between groups, with the non-DS group out performing those with DS. Participants with DS displayed higher resting values of NO when compared to non-DS (Table 1). Reliability of MVIC was 0.68 and 0.79 for IHG and LEP for DS subjects and 0.63 and 0.73 for non-DS peers (Table 2).

Table 1. Age, anthropometrics, hemodynamics, neuromuscular and biochemical data for adolescents with and without Down Syndrome (DS).

\begin{tabular}{lccc}
\hline Variables & Non-DS $(\boldsymbol{N}=\mathbf{1 0})$ & DS $(\boldsymbol{N}=\mathbf{1 1})$ & $\boldsymbol{p}$-value \\
\hline Anthropometrics & $13 \pm 1(12.8-14.6)$ & $14 \pm 1(12.8-15.5)$ & 0.527 \\
Age $(\mathrm{y})$ & $162 \pm 7(156.9-167.1)$ & $149 \pm 9(143.4-156.2)^{*}$ & 0.004 \\
Height $(\mathrm{cm})$ & $53 \pm 5(49.8-57.1)$ & $52 \pm 14(42.8-62.1)$ & 0.831 \\
Body Mass $(\mathrm{kg})$ & $23 \pm 3(21.4-26.4)$ & $25 \pm 8(20.0-31.8)$ & 0.524 \\
Body Fat Mass $(\%)$ & $12 \pm 2(11.02-14.81)$ & $14 \pm 8(8.92-20.3)$ & 0.534 \\
Fat Mass $(\mathrm{kg})$ & $40 \pm 3(38.1-43.0)$ & $37 \pm 6(33.4-42.2)$ & 0.235 \\
FFM $(\mathrm{kg})$ & $20 \pm 1(19.2-21.5)$ & $23 \pm 4(20.11-26.02)$ & 0.084 \\
BMI $\left(\mathrm{kg} / \mathrm{m}^{2}\right)$ & & & \\
Hemodynamic & $106 \pm 9(99.82-112,98)$ & $101 \pm 12(93.15-109.7)$ & 0.316 \\
SBP $(\mathrm{mmHg})$ & $64 \pm 7(58.4-69.8)$ & $63 \pm 10(56.63-70.1)$ & 0.855 \\
DBP $(\mathrm{mmHg})$ & $78 \pm 8(72.45-83.94)$ & $76 \pm 9(69.78-82.33)$ & 0.582 \\
MAP (mmHg) & $72 \pm 10(64.81-80.39)$ & $73 \pm 11(65.63-80.55)$ & 0.920 \\
HR (bpm) & $77 \pm 14(66.99-88.04)$ & $74 \pm 16(63.32-85.6)$ & 0.662 \\
RPP/100 $(\mathrm{bpm} * \mathrm{mmHg})$ & &
\end{tabular}




\section{Neuromuscular indexes}

\section{Handgrip}

MVIC (kg)

$28 \pm 4(25.62-31.98)$

$14 \pm 6(10.78-18.86)^{*}$

0.0001

MVIC relative ( $\mathrm{kg} / \mathrm{FFM})$

$0.71 \pm 0.1(0.62-0.79)$

$0.39 \pm 0.1(0.29-0.49)^{*}$

0.0001

Leg Press

MVIC (kg)

$90 \pm 27(70.14-110.00)$

$69 \pm 38(44.05-95.81)$

MVIC relative ( $\mathrm{kg} / \mathrm{FFM})$

$2.24 \pm 0.7(1.68-2.81)$

$1.93 \pm 1.1(1.16-2.71)$

0.476

\section{Biochemical}
NO Log
$1.7 \pm 0.2(1.61-1.95)$
$2.07 \pm 0.3(1.83-2.31)^{*}$
0.034
$\mathrm{NO}(\mu \mathrm{M})$
$71.1 \pm 49.3(35.86-106.45)$
$158.9 \pm 162.8(33.80-284.15)$
0.122

Data expressed as mean and standard deviation $( \pm \mathrm{SD})$ and $95 \%$ confidence interval $(\mathrm{CI})$ for the mean. DS, Down Syndrome; non-DS, without Down Syndrome; BMI, Body Mass Index; SBP, systolic blood pressure; DBP, diastolic blood pressure; MAP, mean arterial pressure; HR, heart rate; RPP, rate pressure product; MVIC, maximal voluntary isometric contraction; FFM, fat-free mass; NO', nitric oxide; bpm, beats per minute; kg, kilogram;. * $p<0.05$. Fonte: Autores.

There was no time $\mathrm{x}$ group interaction for $\operatorname{SBP}(F[5,95]=1.07, P=0.38)$, DBP $(F[5,95]=2.03, P=0.08)$ or MAP $(F[5,95]=2.06, P=0.07)$ after the LEP test. However, a main effect was found for SBP levels after the LEP test at different time points in the non-DS group $(F[5,95]=4.81, P=0.001)$, but no differences were found for $\operatorname{DBP}(F[5,95]=0.24, P=$ $0.94]$ and $\operatorname{MAP}(F[5,95]=1.40, P=0.22)$.

For IHG test, there was no time $\mathrm{x}$ group interaction for $\operatorname{SBP}(F[4,76]=1.07, P=0.37)$, DBP $(F[4,76]=1.17, P=$ $0.08)$ or $\operatorname{MAP}(F[4,76]=1.17, P=0.32)$. There were no significiant main effects of time for $\operatorname{SBP}(F[4,76]=0.99, P=0.41)$, $\operatorname{DBP}(F[4,76]=1.60, P=0.18)$ or $\operatorname{MAP}(F[4,76]=1.55, P=0.19)($ Fig. 2$)$. 
Figure 2. Blood pressure responses to MVIC in LEP, leg press (A) and HG, handgrip (B) in adolescents with and without Down syndrome (DS).
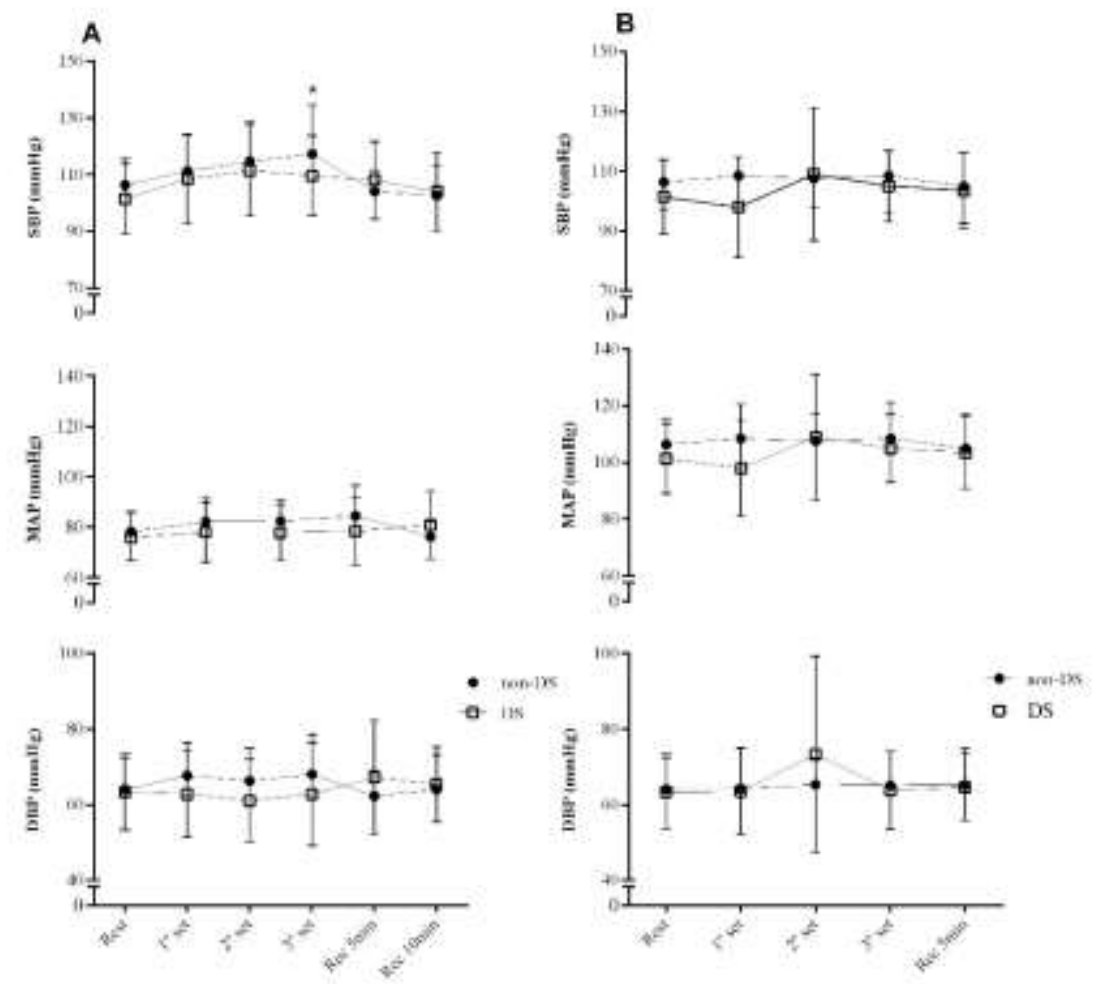

Data expressed as mean and ( \pm ) standard deviation. SBP, systolic blood pressure; DBP, diastolic blood pressure; MAP, mean arterial pressure. *: statistical difference from recovery 10 minutes $(p<0.05)$. Fonte: Autores.

There was no time $\mathrm{x}$ group interaction for $\operatorname{RPP}(F[5,95]=0.98, P=0.43)$ or $\mathrm{HR}(F[5,95]=0.92, P=0.46)$ following the LEP test. However, a main effect of time showed a statistically significant difference for non-DS group for RPP $(F[5,95]=4.98, P=0.001)$ and $\operatorname{HR}(F[5,95]=3.87, P=0.003)$ after the LEP test (Fig. 3). Also, there was no time $\mathrm{x}$ group interaction for $\operatorname{RPP}(F[4,76]=0.69, P=0.59)$ or $\operatorname{HR}(F[4,76]=1.35, P=0.25)$. No main effects of time for RPP $(F[4,76]$ $=1.70, P=0.15)$ or HR were found after the IHG test $(F[4,76]=1.85, P=0.12)$ (Fig. 3$)$.

There was time $\mathrm{x}$ group interaction for $\mathrm{NO}(F[3,48]=4.20, P=0.01)$ for the MVIC test (Fig. 4). Participants with DS had higher NO at baseline $(P=0.034)$, recovery $(P=0.01)$, and the IHG test $(P=0.06)$ compared to non-DS group. Though not significant, a large effect was found for NO across time (baseline and recovery 10 minutes after LEP test). Furthermore, analysis of change revealed that subjects with DS had higher NO compared to non-DS group $(P=0.02)$ during recovery after LEP test, but no differences were observed after IHG test $(P=0.06)$. 
Figure 3. Heart rate (HR) and rate pressure product (RPP) responses to MVIC in LEP, leg press (A) and HG, handgrip (B) in adolescents with and without Down syndrome (DS), Recovery (Rec).
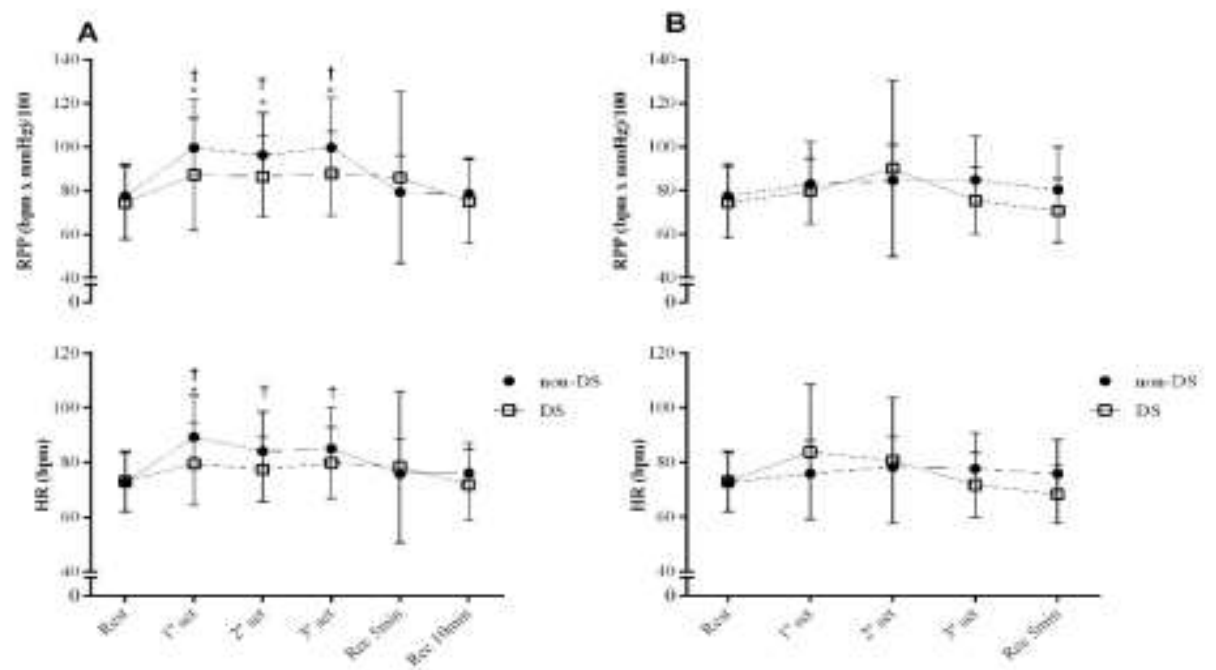

Data expressed as mean and $( \pm)$ standard deviation. $\uparrow$ : statistical difference from baseline $(p<0.05) *$ : statistical difference from recovery 10 minutes $(p<0.05)$. Fonte: Autores.

Figure 4. Individual data of nitric oxide $\left(\mathrm{NO}^{-}\right)$responses to MVIC tests in with and without Down syndrome (DS) adolescents.
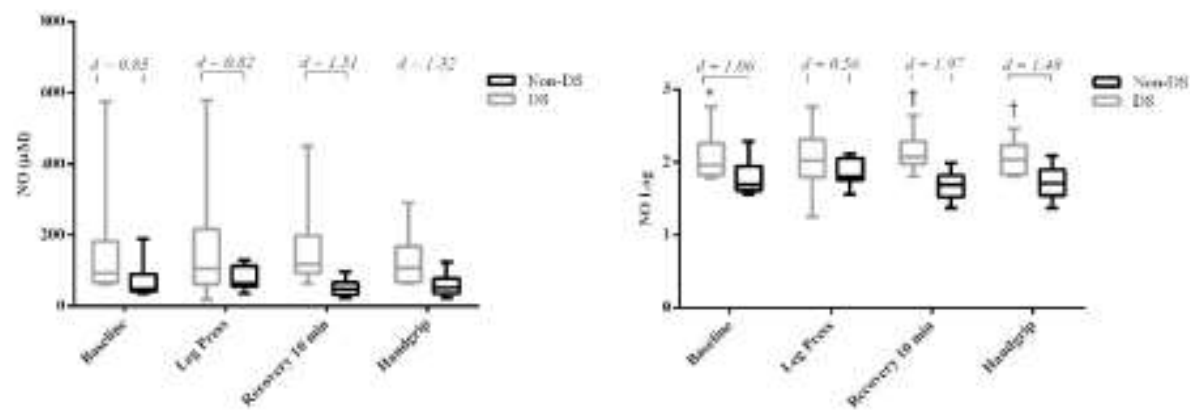

Data expressed as mean and ( \pm ) standard deviation. $d$ : effect size (Cohen’s). *: statistical difference between groups. Fonte: Autores.

For LEP and IHG tests, non-DS subjects had a SRD of $34.58 \mathrm{~kg}(\mathrm{TE}=12.65 \mathrm{~kg})$ and $7.77 \mathrm{~kg}(\mathrm{TE}=2.81 \mathrm{~kg})$, respectively. Also, DS subjects demonstrated a SRD for LEP and IHG tests of $43.87 \mathrm{~kg}(\mathrm{TE}=15.95 \mathrm{~kg})$ and $11.38 \mathrm{~kg}(\mathrm{TE}=$ $4.17 \mathrm{~kg}$ ), respectively (Table 2). Furthermore, the mean differences between groups (12.61 - $15.31 \mathrm{~kg})$ for IHG test was higher than SRD. For LEP test, the differences between groups $(24.03-25.58 \mathrm{~kg})$, was below the SRD. The non-DS group demonstrated a superior magnitude of treatment effect for leg press SBP, MAP, RPP and HR compared to DS group (Table 3). 
Table 2. Test - retest reliability, techinical error and smallest real difference of maximum voluntary isometric contraction in adolescents with and without Down syndrome.

\begin{tabular}{|c|c|c|c|c|c|c|c|c|c|}
\hline \multirow{2}{*}{ Variables } & \multicolumn{4}{|c|}{ Non-DS } & \multicolumn{4}{|c|}{ DS } & \multirow{2}{*}{$\begin{array}{c}\Delta \text { mean } \\
\text { between groups } \\
(\mathrm{kg})\end{array}$} \\
\hline & $\overline{\text { Mean } \pm \text { SD }}$ & ICC & TE (kg) & SRD (kg) & Mean \pm SD & ICC & TE (kg) & SRD (kg) & \\
\hline \multicolumn{10}{|l|}{ Handgrip, kg } \\
\hline $\begin{array}{l}\text { Test } \\
\text { Retest }\end{array}$ & $\begin{array}{l}26 \pm 4 \\
28 \pm 4\end{array}$ & 0.63 & 2.81 & 7.77 & $\begin{array}{l}14 \pm 7 \\
13 \pm 6\end{array}$ & 0.68 & 4.17 & 11.38 & $\begin{array}{l}12.61 \\
15.31\end{array}$ \\
\hline \multicolumn{10}{|l|}{ Leg Press, $k g$} \\
\hline $\begin{array}{l}\text { Test } \\
\text { Retest }\end{array}$ & $\begin{array}{l}78 \pm 25 \\
74 \pm 22\end{array}$ & 0.73 & 12.65 & 34.58 & $\begin{array}{l}54 \pm 35 \\
50 \pm 33\end{array}$ & 0.79 & 15.95 & 43.87 & $\begin{array}{l}24.03 \\
23.58\end{array}$ \\
\hline
\end{tabular}

Data expressed as mean and $( \pm)$ standard deviation. DS, Down syndrome; non-DS, without Down Syndrome; ICC, intraclass correlation coefficient, TE, technical error; SRD, smallest real difference. Fonte: Autores.

Table 3. Values of effect size for main effect of time.

\begin{tabular}{cccc}
\hline \multirow{2}{*}{ Parameters } & & \multicolumn{1}{c}{ Non-DS } & DS \\
& & $\mathrm{f}$ & $\mathrm{f}$ \\
\hline \multirow{6}{*}{ Leg press } & SBP & 0.40 (large) & 0.18 (small) \\
& MAP & 0.31 (medium) & 0.04 (small) \\
& DBP & 0.14 (small) & 0.08 (small) \\
& RPP & 0.64 (large) & 0.08 (small) \\
& HR & 0.60 (large) & 0.06 (small) \\
& SBP & 0.08 (small) & 0.10 (small) \\
\multirow{6}{*}{ Handgrip } & MAP & 0.02 (small) & 0.14 (small) \\
& DBP & 0.02 (small) & 0.14 (small) \\
& RPP & 0.14 (small) & 0.11 (small) \\
& HR & 0.19 (small) & 0.14 (small) \\
\hline
\end{tabular}

$f$, effect size, DS, Down syndrome; non-DS, without Down Syndrome; SBP; systolic blood pressure, MAP; mean arterial pressure, $\mathrm{DBP}=$ diastolic blood pressure, $\mathrm{RPP}=$ rate pressure product, $\mathrm{HR}=$ heart rate. Fonte: Autores.

\section{Discussion}

The present study confirmed the initial hypotheses and provided the following novel findings: 1) Non-DS participants demonstrated a greater treatment effect for SBP, MAP, RPR and HR during LEP test compared to those with DS. 2) As postulated, those with DS had greater saliva NO at baseline, recovery, change values and IHG test when compared to non-DS subjects. 3) Those with DS had lower absolute and relative strength compared to non-DS subjects. Differences for IHG were clinically relevant.

It is likely that the small sample size may have impaired the ability to detect statistical differences between groups. The current investigation was, however, able to assess the practical significance of isometric testing and cardiovascular responses in a population with DS. We support the literature suggesting the added value of an index that measures magnitude of cardiovascular response compared to significance testing alone (McLean \& Ernest, 1998). The current investigators included the effect size to supply information concerning the $p$ values.

Sherman et al., (2021) showed similar findings in that individuals with ID had a blunted BP response to IHG exercise when compared to those without ID. Their MVC values were similar to the current sample, with a small difference between 
groups (DS 2.24\% higher and non-DS 6.44\% higher). Both groups were considered sedentary. Those without DS had a higher treatment effect across time (medium to large effect size) for SBP, RPP and HR during the LEP test compared to DS subjects. There was no difference between groups for IHG. Failure to detect a difference in IHG may be due to a smaller quantity of muscle mass recruited during the IHG assessment, requiring less blood flow and redistribution, leading to a smaller cardiovascular response (Battagin et al., 2010).

There is likely occlusion of the blood flow during IHG due to a mechanical compression of the vessels, resulting in the maintenance of BP modulation in non-DS individuals (Fisher, et al., 2006). On the other hand, a disproportionate blood flow restriction (from the occlusion of the vessels) may occur during the IHG, generating an accumulation of metabolic that can initiate the pressor response (Fisher, et al., 2011). Individuals with DS have a decreased pressor response which may be an indicator of reduced sympathetic activation during IHG; blunted BP and HR were observed in a group with DS compared to a control (Fernhall \& Otterstetter, 2003). Individuals with ID may have difficulty maintaining perfusion pressure during IHG which may decrease metabolic demand and result in attenuated BP response (Sherman, et al., 2021). Similar results were found in our study, as previous studies have demonstrated an attenuated response of hemodynamic responses during IHG and in recovery in adults with DS (Kanokwan Bunsawat \& Baynard, 2016; Fernhall \& Otterstetter, 2003).

The current study demonstrated that isometric exercise targeting large and small muscle groups presented different cardiovascular responses in the non-DS group. This variance between large and small muscle activation was not observed in adolescents with DS. It is possible that the impaired pressor response in individuals with DS may prevent precise cardiovascular tuning between large and small muscle activity (Boulton, et al., 2019; Fisher, et al., 2006). People with DS have blunted vagal withdrawal and sympathetic activation, leading to lower HR and systemic BP (Fernhall, et al., 2013). It was expected that individuals with DS would present lower BP responses (despite age) at rest and exercise when compared to controls (Hu et al., 2013; Morrison et al., 1996). People with DS experience lower BP at rest and exercise due to lower sympathovagal balance and baroreflex control, leading to autonomic dysregulation (Kanokwan Bunsawat \& Baynard, 2016; Heffernan, et al., 2005).

Differences were found for saliva NO between groups. DS subjects displayed a statistically higher saliva NO at baseline, recovery, and IHG test when compared to non-DS peers and a higher $\Delta$ NO. This finding contrasts with the previously reported data wherein there were no acute effects to aerobic exercise (large muscle mass) on nitrate concentration in adolescents with DS immediately after exercise or during recovery (Zambrano, et al., 2009). However, Olher et al. (2020) found greater NO bioavailability and increased the antioxidant reaction after 8 minutes of large muscle isometric exercise consequently reducing BP in young hypertensive participants. This observation could be due to ischemia-reperfusion in the adjacent region during isometric muscle actions; muscle activation increases vascular resistance that is immediately followed by recovery intervals of reperfusion (Gaffney, Sjøgaard, \& Saltin, 1990).

It is important to emphasize the impact of isometric exercise and activated muscle size may influence saliva NO responses. Previous studies have reported isometric exercise improved local blood flow dilation and endothelial function (Badrov et al., 2013; Gaffney, et al., 1990). Isometric exercise may be a valuable modality to improve endothelial function in individuals with DS at a young age (Cappelli-Bigazzi, et al., 2004).

An important finding in this study that confers previous studies was that adolescents with DS had lower absolute and relative strength when compared to non-DS subjects (Heffernan, et al., 2009; Pitetti, et al., 1992). It can be extrapolated that high IHG is associated with a lower risk of premature mortality for adolescents. Assessing IHG is an inexpensive, easy, and practical tool to target early interventions to delay muscle strength decline and prevent future cardiovascular conditions (Ortega, et al., 2012). One way to measure IHG's clinical applicability is to use the SRD, or minimal clinically important 
difference. SRD describes the smallest beneficial effect of intervention that justifies the costs, risks and inconveniences (Dvir, 2015).

Considering the SRD calculated, differences above $11.38 \mathrm{~kg}$ were considered a clinically meaningful change. The mean difference was $13.96 \mathrm{~kg}$ for IHG test between adolescents with and without DS. Considering the SRD for IHG in DS subjects in this study was $11.38 \mathrm{~kg}$, it may be inferred that a mean difference of $13.99 \mathrm{~kg}$ is a clinically meaningful difference between groups. This finding may be influenced by combination of hypotonia, ligament laxity, anthropometric characteristics of the hand (Foley \& Killeen, 2019), and reduced volume in the cerebellum, hippocampus, and white matter of the cortex (Shiohama, Levman, Baumer, \& Takahashi, 2019).

Participants with DS had a lower, but not statistically different absolute and relative LEP strength when compared to non-DS group. The present study demonstrated a mean difference of $23.81 \mathrm{~kg}$ in LEP test for DS when compared to non-DS peers. The SRD for non-DS and DS in regard to LEP was $34.58 \mathrm{~kg}$ and $43.87 \mathrm{~kg}$, respectively. The difference did not reach the SRD but remained above the TE. Thus, differences for lower limbs between groups were not a clinically meaningful difference but remained above the TE.

The results of the present study should be interpreted with caution as some methodological concerns must be addressed. Limitations of this study include 1) heterogeneity between the groups (e.g., variance in participant sex between groups) 2) puberty was not considered 3) despite the verbal encouragement given by the researchers during the MVIC test, adolescents with DS had lower absolute strength (IHG and LEP) than the non-DS group. This can influence the hemodynamic responses of the DS adolescents, as muscle sympathetic nervous activity reflects on the BP and HR pressor response (Boulton, et al., 2019) 4) Even though salivary NO response is useful for understanding physiological processes, the oral cavity is particularly complex and variation in this parameter might not reflect variations in other systems of the body (Diaz, Bocanegra, Teixeira, Soares, \& Espindola, 2013).

Despite the identified limitations, this study has important implications for individuals with ID. This study identified a clinical mean difference between groups for IHG strength. Moreover, employment opportunities in training centers for individuals with ID may demand an appropriate level of muscular strength (e.g., lifting boxes), and the possibility exists that these adolescents when becoming adults may have difficulty performing manual jobs (Pitetti, et al., 1992). Thus, individuals with DS may attain greater daily activities and work opportunities if they maintain high levels of muscular strength.

\section{Conclusion}

The current investigation documented that individuals with DS have a blunted cardiovascular response at rest and after a sympathetic excitatory stimulus when compared to those without DS. This may be related to higher saliva NO at rest and/or lower absolute strength. On the other hand, IHG and LEP is an excellent adjuvant strategy to attenuate and prevent loss of muscle strength and osteoarticular problems. However, exercise prescription needs to be adequate and safe according to cardiovascular responses, as adolescents with DS have blunted BP and HR responses.

Future research should focus on understanding the bioavailability of NO and muscular strength in adolescents with DS. A greater understanding on how lower muscle mass and strength may contribute to lower physical activity and reduced work capacity in this population may explain comorbid conditions that accompany the diagnosis.

\section{Acknowledgments}

The research was carried out in partnership with Projeto Espaço Com-Vivências, which is supported by the Secretary of Education of the Federal District and the Catholic University of Brasilia, Federal District, Brazil, and training laboratory (LAFIT-UCB). Thanks to Ronaldo Benford, MD., for the cardiological evaluation and Fernanda Rodrigues for all support 
during the laboratory tests. This research was funded by a grant from Foundation for Research Support of the Federal District (FAPDF 193.001607/2017), and this study was financed in part by the Coordenação de Aperfeiçoamento de Pessoal de Nível Superior - Brasil (CAPES) - Finance Code 001.

\section{References}

Badrov, M. B., Bartol, C. L., DiBartolomeo, M. A., Millar, P. J., McNevin, N. H., \& McGowan, C. L. (2013). Effects of isometric handgrip training dose on resting blood pressure and resistance vessel endothelial function in normotensive women. European journal of applied physiology, 113(8), 2091-2100.

Battagin, A. M., Dal Corso, S., Soares, C. L., Ferreira, S., Leticia, A., Souza, C., \& Malaguti, C. (2010). Pressure response after resistance exercise for different body segments in hypertensive people. Arq Bras Cardiol, 95(3), 405-411. doi: 10.1590/s0066-782x2010005000117

Baynard, T., Pitetti, K. H., Guerra, M., \& Fernhall, B. (2004). Heart rate variability at rest and during exercise in persons with Down syndrome. Archives of physical medicine and rehabilitation, 85(8), 1285-1290.

Bertapelli, F., Pitetti, K., Agiovlasitis, S., \& Guerra-Junior, G. (2016). Overweight and obesity in children and adolescents with Down syndrome-prevalence, determinants, consequences, and interventions: a literature review. Research in developmental disabilities, 57, 181-192.

Boulton, D., Green, S., Macefield, V. G., \& Taylor, C. E. (2019). A comparison of muscle sympathetic nerve activity to non-contracting muscle during isometric exercise in the upper and lower limbs. Frontiers in neuroscience, 13, 341.

Bunsawat, K., \& Baynard, T. (2016). Cardiac autonomic modulation and blood pressure responses to isometric handgrip and submaximal cycling exercise in individuals with down syndrome. Clinical Autonomic Research, 26(4), 253-260.

Bunsawat, K., Goulopoulou, S., Collier, S., Figueroa, A., Pitetti, K., \& Baynard, T. (2015). Normal HR with tilt, yet autonomic dysfunction in persons with Down syndrome. Medicine and Science in Sports and Exercise, 47(2), 250-256.

Cappelli-Bigazzi, M., Santoro, G., Battaglia, C., Palladino, M. T., Carrozza, M., Russo, M. G., . . . Calabrò, R. (2004). Endothelial cell function in patients with Down's syndrome. The American journal of cardiology, 94(3), 392-395.

Cohen, J. (2013). Statistical power analysis for the behavioral sciences: Routledge.

Diaz, M. M., Bocanegra, O. L., Teixeira, R. R., Soares, S. S., \& Espindola, F. S. (2013). Salivary nitric oxide and alpha-amylase as indexes of training intensity and load. Int J Sports Med, 34(1), 8-13. doi: 10.1055/s-0032-1316318

Dvir, Z. (2015). Difference, significant difference and clinically meaningful difference: The meaning of change in rehabilitation. $J$ Exerc Rehabil, 11 (2), 6773. doi: $10.12965 /$ jer. 150199

Escamilla, R. F., Fleisig, G. S., Zheng, N., Lander, J. E., Barrentine, S. W., Andrews, J. R., . . Moorman, C. T., 3rd. (2001). Effects of technique variations on knee biomechanics during the squat and leg press. Med Sci Sports Exerc, 33(9), 1552-1566.

Faul, F., Erdfelder, E., Lang, A.-G., \& Buchner, A. J. B. r. m. (2007). G* Power 3: A flexible statistical power analysis program for the social, behavioral, and biomedical sciences. 39(2), 175-191.

Fernhall, B., Mendonca, G. V., \& Baynard, T. (2013). Reduced work capacity in individuals with Down syndrome: a consequence of autonomic dysfunction? Exercise and sport sciences reviews, 41(3), 138-147.

Fernhall, B., \& Otterstetter, M. (2003). Attenuated responses to sympathoexcitation in individuals with Down syndrome. Journal of applied physiology, 94(6), 2158-2165.

Figueiredo IM, S. R., Mancini MC, Silva FCM, Souza MAP. (2007). Test of grip strength using the Jamar dynamometer. . Acta Fisiátrica, , 14(2).

Fisher, J. P., Ogoh, S., Dawson, E. A., Fadel, P. J., Secher, N. H., Raven, P. B., \& White, M. J. (2006). Cardiac and vasomotor components of the carotid baroreflex control of arterial blood pressure during isometric exercise in humans. The Journal of physiology, 572(3), 869-880.

Fisher, J. P., Young, C. N., \& Fadel, P. J. (2011). Autonomic adjustments to exercise in humans. Comprehensive Physiology, 5(2), 475-512.

Foley, C., \& Killeen, O. G. (2019). Musculoskeletal anomalies in children with Down syndrome: an observational study. Archives of disease in childhood, $104(5), 482-487$.

Gaffney, F., Sjøgaard, G., \& Saltin, B. (1990). Cardiovascular and metabolic responses to static contraction in man. Acta physiologica scandinavica, 138(3), $249-258$.

Ginis, K. A. M., van der Ploeg, H. P., Foster, C., Lai, B., McBride, C. B., Ng, K., . . Vásquez, P. M. (2021). Participation of people living with disabilities in physical activity: a global perspective. The Lancet.

Heffernan, K. S., Baynard, T., Goulopoulou, S., Giannopoulou, I., Collier, S. R., Figueroa, A., \& Fernhall, B. (2005). Baroreflex sensitivity during static exercise in individuals with Down syndrome. Medicine and science in sports and exercise, 37(12), 2026.

Heffernan, K. S., Sosnoff, J. J., Ofori, E., Jae, S. Y., Baynard, T., Collier, S. R., . . Pitetti, K. H. (2009). Complexity of force output during static exercise in individuals with Down syndrome. Journal of applied physiology, 106(4), 1227-1233.

Hu, M., Yan, H., Ranadive, S. M., Agiovlasitis, S., Fahs, C. A., Atiq, M., . . Fernhall, B. (2013). Arterial stiffness response to exercise in persons with and without Down syndrome. Research in Developmental Disabilities, 34(10), 3139-3147. 
Leti, T., Guinot, M., Favre-Juvin, A., \& Bricout, V.-A. (2015). Difference of catecholamine responses to exercise in men with trisomy 21, with or without chronotropic incompetence. Physiology \& behavior, 142, 97-103.

Levin, K. A. (2006). Study design III: Cross-sectional studies. Evidence-based dentistry, 7(1), 24-25.

McLEAN, J. E., \& Ernest, J. M. J. R. i. t. S. (1998). The role of statistical significance testing in educational research. 5(2).

Morrison, R. A., McGrath, A., Davidson, G., Brown, J. J., Murray, G. D., \& Lever, A. F. (1996). Low blood pressure in Down's syndrome: a link with Alzheimer's disease? Hypertension, 28(4), 569-575.

Nascimento, E. F., Souza, M. K., Rosa, T. S., Melo, R., Leite, G., Sores, A., . . Vanerson, R. (2016). Predictive Equation for Fat Percentage Based on Body Mass Index for Adolescents with Down Syndrome. Journal of Exercise Physiology Online, 19(4).

Olher, R. R., Rosa, T. S., Souza, L. H. R., Oliveira, J. F., Soares, B. R. A., Ribeiro, T. B. A., . . Moraes, M. R. (2020). Isometric Exercise with Large Muscle Mass Improves Redox Balance and Blood Pressure in Hypertensive Adults. Med Sci Sports Exerc, 52(5), 1187-1195. doi: 10.1249/MSS.0000000000002223

Ortega, F. B., Silventoinen, K., Tynelius, P., \& Rasmussen, F. (2012). Muscular strength in male adolescents and premature death: cohort study of one million participants. BMJ, 345, e7279. doi: 10.1136/bmj.e7279

Pickering, T. G., Hall, J. E., Appel, L. J., Falkner, B. E., Graves, J., Hill, M. N., . . Roccella, E. J. (2005). Recommendations for blood pressure measurement in humans and experimental animals: part 1: blood pressure measurement in humans: a statement for professionals from the Subcommittee of Professional and Public Education of the American Heart Association Council on High Blood Pressure Research. Hypertension, 45(1), 142-161.

Pitetti, K. H., Climstein, M., Mays, M. J., \& Barrett, P. J. (1992). Isokinetic arm and leg strength of adults with Down syndrome: a comparative study. Archives of physical medicine and rehabilitation, 73(9), 847-850.

Portney, L. G., \& Watkins, M. P. (2009). Foundations of clinical research: applications to practice (Vol. 892): Pearson/Prentice Hall Upper Saddle River, NJ.

Presson, A. P., Partyka, G., Jensen, K. M., Devine, O. J., Rasmussen, S. A., McCabe, L. L., \& McCabe, E. R. (2013). Current estimate of Down syndrome population prevalence in the United States. The Journal of pediatrics, 163(4), 1163-1168.

Roizen, N. J., \& Patterson, D. (2003). Down's syndrome. The Lancet, 361(9365), 1281-1289.

Romitelli, F., Santini, S. A., Chierici, E., Pitocco, D., Tavazzi, B., Amorini, A. M., . . . Di Stasio, E. (2007). Comparison of nitrite/nitrate concentration in human plasma and serum samples measured by the enzymatic batch Griess assay, ion-pairing HPLC and ion-trap GC-MS: the importance of a correct removal of proteins in the Griess assay. J Chromatogr B Analyt Technol Biomed Life Sci, 851(1-2), 257-267. doi: 10.1016/j.jchromb.2007.02.003

Santana, H. A., Moreira, S. R., Asano, R. Y., Sales, M. M., Córdova, C., Campbell, C. S., . . Simoes, H. G. (2013). Exercise intensity modulates nitric oxide and blood pressure responses in hypertensive older women. Aging clinical and experimental research, 25(1), 43-48.

Sherman, S. R., Schroeder, E. C., Baynard, T., Fernhall, B., \& Hilgenkamp, T. I. (2021). Hemodynamic Response to Isometric Handgrip Exercise in Adults with Intellectual Disability. Medicine and Science in Sports and Exercise, 53(3), 606.

Shields, N., Downs, J., de Haan, J. B., Taylor, N. F., Torr, J., Fernhall, B., . . Leonard, H. (2018). What effect does regular exercise have on oxidative stress in people with Down syndrome? A systematic review with meta-analyses. Journal of science and medicine in sport, 21(6), 596-603.

Shiohama, T., Levman, J., Baumer, N., \& Takahashi, E. (2019). Structural magnetic resonance imaging-based brain morphology study in infants and toddlers with Down syndrome: the effect of comorbidities. Pediatric neurology, 100, 67-73.

Siri, W. E. (1993). Body composition from fluid spaces and density: analysis of methods. 1961. Nutrition, 9(5), 480-491; discussion 480, 492.

Subramaniam, P., Girish Babu, K., \& Mohan Das, L. (2014). Assessment of salivary total antioxidant levels and oral health status in children with Down syndrome. Special Care in Dentistry, 34(4), 193-200.

Swinton, P. A., Hemingway, B. S., Saunders, B., Gualano, B., \& Dolan, E. (2018). A Statistical Framework to Interpret Individual Response to Intervention: Paving the Way for Personalized Nutrition and Exercise Prescription. Front Nutr, 5, 41. doi: 10.3389/fnut.2018.00041.

Zambrano, J. C., Marquina, R., Sulbarán, N., Rodríguez-Malaver, A. J., \& Reyes, R. A. (2009). Aerobic exercise reduced oxidative stress in saliva of persons with Down syndrome. Research in Sports Medicine, 17(3), 195-203. 